\title{
The Role of Green Recruitment and Selection on Performance of Processing Industries in Tanzania: A Case of Tanzania Tobacco Processors Limited (TTPL)
}

\author{
Kelvin M Mwita \\ Assistant Lecturer, \\ Mzumbe University, Morogoro, Tanzania \\ kmwita@mzumbe.ac.tz \\ Dr. Stella Malangalila Kinemo $(\mathrm{PhD})$ \\ Senior Lecturer, \\ Mzumbe University, Morogoro, Tanzania
}

Received: Jul. 3, 2018 Accepted: Sep.25, 2018 Online published: Oct. 11, 2018

doi:10.5296/ijhrs.v8i4.13356

URL: https://doi.org/10.5296/ijhrs.v8i4.13356

\begin{abstract}
Environmental conservation has been a concern to many international, local organizations and individuals for Centuries. Green management initiatives become an important factor in forward-thinking business around the world as a means of combating environmental degradation caused by organizations. Moreover, industrialization has contributed to the global environmental problems we are witnessing today and Tanzania industrialization drive cannot ignore this fact. Research is one of best ways for investigating, understanding and solving problems. Although number of researches has been done on Green Human Resource Management (Green HRM), still there is no sufficient literature on the subject. To bridge this gap this study investigated the role of green recruitment and selection on performance of processing industries in Tanzania by using Tanzania Tobacco Processors Limited (TTPL) as a case study. The study sough to specifically assess the application of green recruitment and selection at TTPL, determining whether green recruitment and selection attract more and better job candidates, and establishing the relationship between green recruitment and selection and organizational performance. It was found that green recruitment and selection practices are in place and they contribute in attracting more qualified job candidates. The
\end{abstract}


study also found a linear relationship between green recruitment and selection and performance. Further, the study recommends institutionalization of green recruitment and selection and other green HRM practices in order improve organizational performance. Regulatory and statutory bodies are recommended to ensure that green practices are put in place by organizations for organizational and environmental sustainability.

Keywords: green recruitment, green selection, green HRM, organizational performance

\section{Introduction}

Environmental conservation has been a concern to many international, local organizations and even individuals for Centuries (Ahmad, 2015). In recent times the importance of environmental issues and sustainable development has increased both in the developed and developing nations. Growing concern for global environment and the development of international standards for environmental management has created a need for business to adopt "green practices" (Sharma \& Gupta, 2014). Green management initiatives become an important factor in forward-thinking business around the world (Sudin, 2011). Understanding and increasing the scope and depth of green HRM practices, organizations can improve their environmental performance in a more sustainable manner than before. The green HRM practices are more powerful tools in making organisations and their operations green (Arulrajah et al, 2015). Green Human Resource Management is the use of HRM policies to promote sustainable use of resources within business organizations and, more generally, promote the cause of environmentalism (Dutta, 2012).

Although industrialization focuses on achieving economic development it has resulted in global environmental degradation (Park, 1998). It has also contributed to the global environmental problems we are witnessing today. Issues like global warming, climate change, ozone depletion, acid rain, proliferation of persistent organic pollutants etc. are some known environmental problems associated with industrial processes. Tanzania industrialization drive cannot ignore this fact (Katima, 2017)

Research is one of best ways for investigating, understanding and solving problems. Although number of researches has been done on Green Human Resource Management (Green HRM), still there is no sufficient literature on the subject (Sudin, 2011; Marhatta, 2013; Jabbar \& Abid, 2015). This necessitates the need for more researches in Green HRM to provide for empirical information that will bring positive impacts to the field. To bridge this gap this study investigated the relationship between green recruitment and selection and performance of processing industries in Tanzania by using Tanzania Tobacco Processors Limited (TTPL) as a case study.

Green recruitment and selection (GRS) has been viewed as an important component in GHRM practices (Ahmand, 2015). Candidates' green awareness is the basic aspect of Green Recruitment and Selection, and involves personality factors that enable organizational environmental goals to be achieved, such as green consciousness, conscientiousness, and the agreeableness of candidates (Tang et al, 2018). The profile of a fresh job aspirant ready to enter the job market is changing. Apart from being young, enthusiastic, eager to grab 
opportunities, confident, friendly, they have a high sense of awareness of the most serious and current issues, political, social and environmental (Kaur, 2013). Green recruitment process works with companies throughout the process to define the talents, skills, knowledge and abilities of top performers and manage the process from start to finish and also it applies in our day to day life to ensure the importance of it in the future (Saini \& Shukla, 2016). It is believed that recruiting candidates who are eco-friend will help in improving environmental and organizational performance of firms (Bhutto \& Auranzeb, 2016). So in the present study we investigated application of green recruitment and selection and whether practicing green recruitment and selection has an impact on attracting job candidates. Moreover, the study sought to investigate the relationship between green recruitment and selection and organizational performance

\section{Literature Review}

\subsection{Recruitment and Selection}

Recruitment and selection practices are the fulcrum on which all human resources management functions operate, as without the right staff chosen using the right methods, none of the other functions will operate successfully (Tomčíková, 2016). Recruitment and selection are the two phases of the employment process but there is a difference between them (Oaya, Ogbu \& Remilekun, 2017). Recruitment is the process of searching prospective employees to apply for the job posting in the organizations and selection is the process of choosing appropriate applicants among the job applicants (Singh et al, 2017).

Successful recruitment and selection practices are key components at the entry point of human resources in any organization. Effective recruitment and selection strategies result in improved organizational outcomes (Naveen \& Raju, 2014). This has been proved by a number of empirical studies. The study of Mustapha, Ilesanmi and Aremu (2013) which examined the impacts of well-planned recruitment and selection process on corporate performance in Nigerian banking industry found that there is a significant relationship between recruitment and selection based on merit and organizational performance; that effective recruitment and selection is a key to organizational commitment; that a well-planned recruitment and selection contributes to organizational performance.

Another study by Gamage (2014) sough to establish the relationship between recruitment and selection practices as independent variables and business performance of SME's in Japan as a dependent variable. The study found a positive correlation between recruitment and selection in two sub variables of business performance which are operational and financial performance.

The study of Lushuku (2014) attempted to assess the effectiveness of recruitment and selection in Tanzania public sectors using Tanzania Revenue as a case study. The study found a number of challenges that affect recruitment and selection which in turn affect performance of organizations. It was further found that the challenges have led to unnecessary complaints towards the organization. Moreover, the organization has ended up hiring individuals who were less competent. 


\subsection{Green Recruitment and Selection}

Green recruitment and selection refers to the procedure of hiring people having behavior, knowledge and skills of environment management systems in the organization (Obaid \& Alias, 2015). In green recruitment and selection applications are invited through online mediums like e-mail, online application forms or the global talent pool. If possible, telephone or video-based interviews are conducted to minimize any travel-related environmental impact (Saini \& Shukla, 2016). Since recruitment deals with attracting prospective candidates to apply for available job vacancies in organizations either internally or externally, this can be used as a platform to attract employees who not only have skills and knowledge on environmental conservation but also have an interest to conserve the environment. Recruiting candidates with green bend of mind makes it easy for firms to induct professionals who are aware of sustainable processes and are already familiar with basics like recycling, conservation, and creating a more logical world (Sanyal, 2017). In United Kingdom environmental issues have an impact on organizations recruitment efforts, and according to a survey high-achieving graduates judge the environmental performance and reputation of a company as a criterion for decision-making when applying for job vacancies (Wehrmeyer, 1996; Oates, 1996 in Arulrajah et al, (2015). Siemens, Mannesmann, Bayer and BASF are some examples from German firms who use a green image and environment friendly activities for attracting highly-talented employees (Obaid \& Alias, 2015).

\subsection{Organizational Performance}

Continuous performance is the objective of any organization because only through performance, organizations are able to grow and progress (Gavrea, Ilies \& Stegerean, 2011). Tavana, Szabat, and Puranam (2017) see organizational performance as how well an organization is doing to reach its vision, mission, and goals. This definition is similar to that provided by Daft (2000) which explains that organizational performance means the organizational ability to accomplish its aims. Kasturi (2006) in Amadi, (2014) explained that performance of an organization is the outcome of acrostic of individuals and units of the organization. Except for the external influences on individual behavior and personal traits, organizations can either influence or control all factors affecting performance of individuals and units through formal and informal means. All the above definitions provides a clear understanding that organizational performance is the extent to which an organization is achieving what it intends to achieve.

\subsection{Resource Based View Theory}

The core of the resource-based theory of the firm lies in a fundamental heterogeneity in the production processes of firms. Given certain inputs, each firm will apply these inputs in a different way, resulting in different outputs or products. As a consequence, sustained competitive advantage will result for those firms whose production process proves to be most efficient and whose outputs best meet demand. Inputs are usually divided in three categories: physical resources, organizational resources and human resources (Koch \& Kok, 1999).

Barney (2001) stressed that these resources are bundles of tangible and intangible assets, 
including a firm's management skills, its organizational processes and routines, and the information and knowledge. Resources are important to the organizations since they are valuable, rare, costly to imitate, and non-substitutable (Armstrong \& Shimizu, 2007).

Basing on this theory a competitive advantage can be gained by a firm if human resources are acquired and developed hence possess competences that cannot be imitated by its rivals (Hamel \& Prahalad, 1989 in Armstrong, 2006). This entails that organizations are supposed to create environment that attract employees that can meet organizational needs and that allows continuing learning of their employees in various ways.

Since organizational functions and operations have to be aligned with environmental conservation practices, HRM has an important role to make sure that is achieved through Green HRM. This means acquiring 'green employees' will help organizations having more resourceful human resource that are the source of competitive advantage for better organizational performance. This entails how green recruitment and selection is crucial in ensuring that firms have human resource with sufficient green knowledge and skills.

\subsection{Green Recruitment and Organizational Performance}

The study of Haridas and Sivasubramanaian (2016) investigated the degree of impact of Green HRM practices on firm performance. One of the independent variables studied was green recruitment. From the model used, regression coefficient for green recruitment was 0.144 , which implies that one unit variation (increase) in green recruitment results in 0.144 unit variations (increase) in firm performance if other independent variables are kept constant. The value of ' $t$ ' is 2.119 which is significant at .05 . This shows that the variable green recruitment had positive impact on firm performance. These findings are consistent with those of Bhutto \& Auranzeb (2016) which examined the effects of Green Human Resources Management on firm performance using Pakistan firms and found that green recruitment positively influences performance of the firms.

The study of Sriram and Suba (2018) observed that the significant of Ecological Human Resource Management practices is very essential to promote corporate benefits. The study further opined that by applying the Green Human Resource practices the environment can get away from the natural damages. However, the study found that some employees find difficult in adopting green human resource management. Another study by Javed \& Cheema (2017) investigated the impacts of the adoption of green HRM in the agricultural industry. Among other green HRM practices the study specifically investigated impact of green recruitment and selection practices in the agricultural sector. It was found that green recruitment and selection positively associated with organizational outcomes. Since the agricultural sector is directly linked to environment the application of green recruitment and selection in the sector will have a double advantage. Firstly, it may help in conserving the environment and secondly, helping firms involving in agriculture to attain superior performance.

\subsection{Conceptual Framework}

Conceptual framework is a network, or "a plane," of interlinked concepts that together provide a comprehensive understanding of a phenomenon or phenomena (Jabareen, 2009). 


\section{Macrothink}

International Journal of Human Resource Studies

ISSN 2162-3058

2018, Vol. 8, No. 4

Figure 1 shows conceptual framework of the study. The underlying assumption for the study is that organizational performance which is the dependent variable is influenced by the independent variables which are green recruitment and green selection practices.

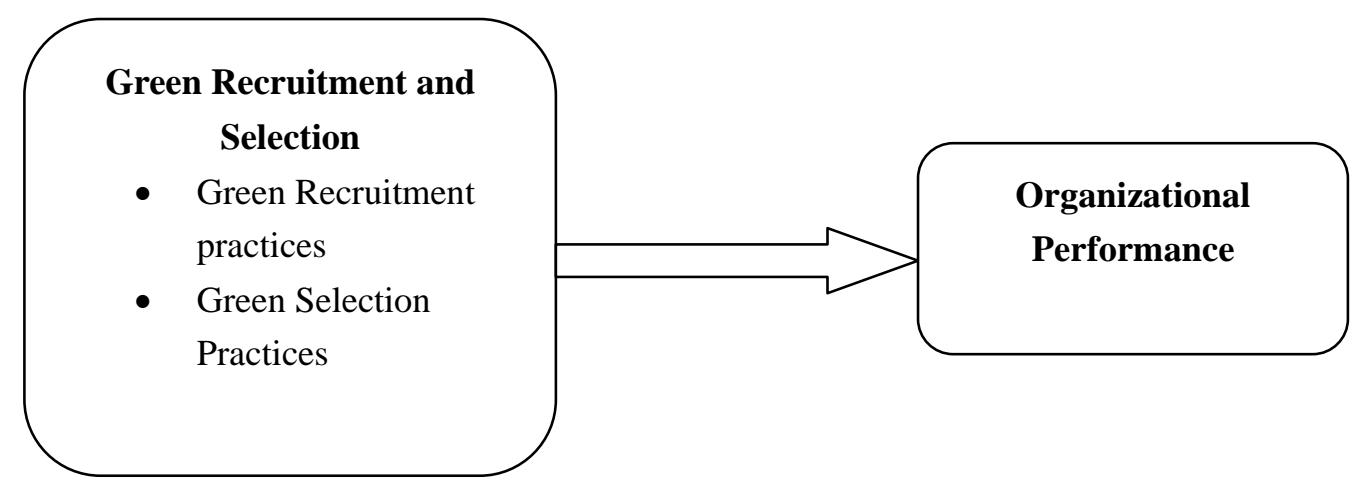

Figure 1. Conceptual Framework.

Source: Researchers' own construct

\subsection{Study Hypotheses}

The following hypotheses were tested in this study;

$\mathrm{H}_{1}=$ There is significant relationship between green recruitment and selection and performance of TTPL

Ho $=$ There is no significant relationship between green recruitment and selection and performance of TTPL

\section{Methodology}

The study used a case study design through which Tanzania Tobacco Processors Limited (TTPL) located in Morogoro Municipality, Tanzania was selected. Case study was used to enable intensive investigation and obtain reliable information for a conclusion and generalization. Tanzania Tobacco Processors Ltd (TTPL) is a private company wholly owned by the Universal Leaf Tobacco with headquarters in Morogoro Municipality, which is about 200 Kilometers west of Dar es Salaam in Tanzania. The Universal Leaf Tobacco was founded in 1918 with headquarters in Richmond, Virginia. It is the largest independent leaf tobacco company in the world dealing with tobacco production and has more than 26,000 employees globally. The company business profile includes, selecting, buying, shipping, processing, packaging, storing and financing of leaf tobacco.

The Company was selected due to its global business experience considering the fact that Green Human Resource Management is, to the large extent, practiced by international organizations as the literature shows. Data was collected using questionnaires and interviews. Interview was used to collect data from the company's Human Resource Manager and questionnaires were used to collect data from the rest of the respondents (employees). Purposive and random sampling technique was used to sample the Human Resource Manager and other employees of TTPL respectively. A total of 72 respondents out of 212 permanent employees of the company were sampled for the study. The sample size made $34 \%$ of the 
total population. According to Borg and Gall (2003) at least 30\% of the total population is representative. This made 72 respondents sufficient for this study. Descriptive data analysis was applied using content analysis to analyze qualitative data while regression analysis was used to analyze quantitative data. Cranach's Alpha Coefficient was used to test reliability of the questionnaire used for data collection. The coefficient was found to be 0.81 and since $0.81>0.7$ the questionnaire used was reliable hence fit for data collection. In order to test for validity of the questionnaire a pilot study was done to 9 respondents who filled the questionnaires and later explained difficulties they faced in understanding the questions asked. Necessary adjustments were made to make sure the questions asked in the questionnaires were well understood. Hence, the questionnaires were reliable and valid for data collection.

\section{Results}

\subsection{Demographic Characteristics}

The study involved a total of 72 respondents from which 46 (63.9\%) were males and 26 (36.1\%) were females. Out of all respondents 2 were between the age of 18 and 24, 41 between the age of 25 and 34, 21 were between the age of 35 and 44, 5 between the age of 45 and 54 and 3 respondents were above 55 years of age.

Additionally, respondents had different levels of education. Twenty three (23) respondents (31.9\%) had certificate qualification, 15 respondents $(20.8 \%)$ had diploma qualification, 30 respondents $(41.7 \%)$ possessed bachelor degree, 2 respondents $(2.8 \%)$ had postgraduate diploma and 2 others (2.8\%) master degree qualification.

\subsection{Application of Green Recruitment and Selection at TTPL}

Respondents were asked to express their level of agreement on various statements relating to green recruitment and selection. They were asked to express their opinions on whether job adverts at TTPL attract people who are knowledgeable on environmental issues. Out of 72 respondents 3 respondents $(4.2 \%) \quad$ strongly disagreed, 2 respondents $(2.8 \%)$ disagreed, 12 respondents $(16.7 \%)$ undecided while 43 respondents $(59.7 \%)$ agreed and 12 respondents $(16.7 \%)$ strongly agreed. This shows that $76.4 \%$ of the respondents believed that job adverts at TTPL attract people who have knowledge on issues relating to environment. As the matter of fact recruitment is like a door for people to enter an organization, preparing a job advert which directly or indirect discriminates job applicants based on knowledge they have concerning environmental issues increases a chance for an organization to have employees with 'green mindsets'.

In responding to the statement stated that job interviews at TTPL use environmental knowledge as one of the criteria for one to secure a job, $15.3 \%$ disagreed, $22.2 \%$ undecided and $62.5 \%$ of the respondents were in agreement with the statement. 
Table 2. Application of Green Recruitment and Selection Responses

\begin{tabular}{|c|c|c|c|c|c|}
\hline Statements & SD & D & $\mathbf{N}$ & $\mathbf{A}$ & SA \\
\hline $\begin{array}{l}\text { Job adverts at TTPL attract } \\
\text { people who are knowledgeable on } \\
\text { environmental issues }\end{array}$ & $\begin{array}{l}3 \\
(4.2 \%)\end{array}$ & $\begin{array}{l}2 \\
(2.8 \%)\end{array}$ & $\begin{array}{l}12 \\
(16.7 \%)\end{array}$ & $\begin{array}{l}43 \\
(59.7 \%)\end{array}$ & $\begin{array}{l}12 \\
(16.7 \%)\end{array}$ \\
\hline $\begin{array}{l}\text { Interviews at TTPL use } \\
\text { environmental knowledge of } \\
\text { candidates as one of criteria for } \\
\text { one to secure a job }\end{array}$ & $\begin{array}{l}3 \\
(4.2 \%)\end{array}$ & $8(11.1 \%)$ & $\begin{array}{l}16 \\
(22.2 \%)\end{array}$ & $\begin{array}{l}31 \\
(43.1 \%)\end{array}$ & $\begin{array}{l}14 \\
(19.4 \%)\end{array}$ \\
\hline
\end{tabular}

$\mathrm{SD}=$ Strongly Disagree, $\mathrm{D}=$ Disagree, $\mathrm{N}=$ Neutral, $\mathrm{A}=$ Agree, $\mathrm{SA}=$ Strongly Agree

\subsection{Attraction of Organizations practicing GHRM to Job Candidates}

The study aimed at seeking for respondents' opinions on whether people are more attracted to work with organizations that are environmental friendly than those which are not. Seven percent $(7 \%)$ of the respondents disagreed, $12.5 \%$ undecided while $80.6 \%$ respondents were in agreement with the statement. This implies that organizations which use environmental practices are likely to have bigger pool of candidates than those that do not. Having larger pool gives organizations more and probably better options in choosing who to hire. These findings are supported by a number of studies. Patil and Sarode (2018) found that in order to improve organization's image and to attract young and quality staff hence Green HRM practices can be used as one of ways of branding an organization. A survey which was done by the British Carbon Trust shows over 75\% of 1018 employees considering working for firms that have an active policy to reduce carbon emissions (Felgate, 2006 in Renwick, Redman \& Maguire, 2012). The study of Alurlajah, Opatha \& Nawaratne, 2015 also concluded that environmentally responsible employers can attract talents needed to implement corporate environmental management initiatives and ultimately contributing in achieving organization's environmental goals

\subsection{Relationship between Green Recruitment and Selection and Organizational Performance}

In responding to the question of whether green recruitment and selection influence organizational performance, $12.5 \%$ of the respondents disagreed, $11.8 \%$ undecided, while $76.4 \%$ were in agreement with the statement. In responding to the same question the Human Resource Manager of TTPL had this to say;

"Investors are nowadays more concerned about environment conservation. They want to invest in a company where employees care for green practices and they want that to be reflected even in our HR policies. So green recruitment and selection directly convinces investors that our organization cares for environment and hence they become willing to invest. Secondly, it helps the company to comply with legal and ethical requirements hence help us to avoid unnecessary legal consequences which may affect our performance negatively"

To examine the relationship between green recruitment and selection and organizational performance the study used a simple linear regression model since it involved only one independent variable.

The model tested in the study is represented as; 
$\mathrm{Y}=\beta_{\mathrm{o}}+\beta_{1} \mathrm{X}_{1}+\varepsilon$

Where;

$\mathrm{Y}=$ Dependent variable (Organizational Performance)

$\beta o=$ Constant

$\mathrm{X}_{1}=$ Independent variable (Recruitment and Selection)

$\beta_{1}=$ Coefficient of independent variable

$\varepsilon=$ error term

Table 3. Model Summary

\begin{tabular}{l|l|l|l|l}
\hline Model & R & R Square & Adjusted R Square & Std. Error of the Estimate \\
\hline 1 & $.659^{\mathrm{a}}$ & .435 & .392 & .638 \\
\hline
\end{tabular}

$\mathrm{R}$ Square is represented by 0.435 which implies that $43.5 \%$ of the variation in organizational performance can be explained by one unit change in green recruitment and selection practices.

Table 4. ANOVA Table

\begin{tabular}{l|l|l|l|l|l|l}
\hline Model & & & Df & $\begin{array}{l}\text { Mean } \\
\text { Square }\end{array}$ & F & Sig. \\
\hline & Regression & 20.647 & 5 & 4.8129 & 10.149 & $.000^{\mathrm{b}}$ \\
\hline 1 & Residual & 26.853 & 66 & .407 & & \\
\hline & Total & $\mathbf{4 7 . 5 0 0}$ & $\mathbf{7 1}$ & & & \\
\hline
\end{tabular}

a. Dependent Variable: Organizational Performance

b. Predictor: (Constant): Green Recruitment and Selection

The model analysis of variance (ANOVA) indicates $\mathrm{F}(5,66)=10.149, \mathrm{P}<.05$. From the $\mathrm{F}$ statistics table the critical value is 2.354 hence the null hypothesis is rejected and the alternative hypothesis accepted since tabulated value (2.354) is greater than the level of significance (0.05). It is hereby concluded that there is statistically significant evidence at $\alpha=0.05$ that shows a positive linear relationship between green recruitment and selection as an independent variable and organizational performance as a dependent variable. These findings are consistent with those of Bhutto \& Auranzeb (2016); Sriram and Suba (2018); and Javed \& Cheema (2017) which found a positive relationship between green recruitment and selection and organizational performance.

\section{Conclusion and Recommendations}

TPPL has put in place green recruitment and selection practices which are observed through job adverts, and job candidate assessment process. The study found that organizations which practices green recruitment and selection are likely to attract more and better job applicants than those which do not. Further, there is significant evidence at $\alpha=0.05$ that shows a positive 
linear relationship between green recruitment and selection and performance at TTPL hence it can be generalized that processing industries can increase their performance by effectively implementing green recruitment and selection practices.

The study recommends that, organizations specifically processing industries should ensure that they put in place green recruitment and selection practices in order to improve their performance and comply with statutory and ethical standards. To ensure that green recruitment and selection practices are effectively implemented organizations should seek to include the agenda in their policies for reference and formalizing these practices. Government through various statutory and regulatory organs should formulate a framework that not only requires processing industries and other organizations to comply with green human resource management practices but also make a serious follow-up to ensure that these practices are institutionalised.

\section{References}

Ahmad, S. (2015). Green Human Resource Management: Policies and practices. Cogent Business \& Management. https://doi.org/10.1080/23311975.2015.1030817

Amadi, E. J. (2014). The Effect of Training and Development on Employees'Performance; at Safaricom Limited Call Centre. Master's Research Project at University of Nairobi, Nairobi.

Armstrong, M. (2006). A Handbook of Human Resource Management Practice. Kogan Page Publishers, New Jersey.

Aruljah, A., Opatha, H. H., \& Nawaratne, N. N. (2015). Green Human Resource Management Practices: A Review. Sri Lankan Journal of Human Resource Management, 5(1), 1-16. https://doi.org/10.4038/sljhrm.v5i1.5624

Barney, J. B. (2001). Is the Resource-based "view" a Useful Perspective for Strategic. Management Research? Academy of Management Review, 26(1), 41-56.

Bhutto, S., \& Auranzeb. (2016). Effects of Green Human Resources Management on Firm Performance: An Empirical Study on Pakistani Firms. European Journal of Business and Management, 8(16), 119-125.

Borg, W. R., \& Gall, M. D. (2003). Educational Research: An Introduction (5th ed.) New York: Longman.

Daft, R. L. (2000). Organizational Theory and Design. (7th Ed.). South-West College Publishing. New Yourk.

Dutta, S. (2012). Greening People: a Strategic Dimension. ZENITH International Journal of Business Economics \& Management Research, 2(2), 143-148.

Gamage, A. S. (2014). Recruitment and Selection Practices in Manufacturing SMEs in Japan: An analysis of the link with business performance. Ruhuna Journal of Management and Finance, 1(1), 37-52.

Gavrea, C., Ilies, L., \& Stegerean, R. (2011). Determinants of Organizational Performance: 
The Case of Romania. Management \& Marketing Challenges for the Knowledge Society, 6(2), 285-300.

Haridas, P., \& Sivasubramanaian. (2016). Impact of Green HRM Practices on Firm Performance: With Special Reference to Manufacturing Industry. International Journal of Engineering Technology Science and Research, 3(12), 49-54.

Jabaree, Y. (2009). Building a Conceptual Framework: Philosophy, Definitions, and Procedure. International Journal of Qualitative Methods, 8(4), 49-62. https://doi.org/10.1177/160940690900800406

Javed, F., \& Cheema, S. (2017). An Empirical Investigation on the Impacts of The Adoption of Green HRM In The Agricultural Industry. Journal of Internet Banking and Commerce, 22(8), 2-14.

Katima, Y. (2017). Enhancement of Industrial Development While Ensuring Sustainable. Environmental Protection In Tanzania: The Need to Balance The Opposing Demands. University of Dar es Salaam, College of Engineering and Technology Department of Chemical and Mining Engineering.

Kaur, H. (2013). Today's Success Mantra-Going Green at Functional Areas of HRM. International Journal of Management \& Business Studies, 3(1), 96-99.

Koch, C., \& Kok, J. (1999). A Human-Resource-Based Theory of the Small Firm. Small Business Research and Consultancy.

Lushiku, L. (2014). Assessment on the Effectiveness of Recruitment And Selection Process In Public Sectors: A Case of Tanzania Revenue Authority (TRA). Master's Dissertation at Mzumbe University, Dar-es-Salaam.

Mustapha, A. M., Ilesanmi, O., \& Aremu, M. (2013). The Impacts of well Planned Recruitment and Selection Process on Corporate Performance in Nigerian Banking Industry (A Case Study of First Bank Plc 2004-2011). International Journal of Academic Research in Business and Social Sciences, 3(9), 633-648.

Oaya, Z., Ogbu, O. J., \& Remileku, O. G. (2017). Impact of Recruitment and Selection Strategy on Employees' Performance: A Study of Three Selected Manufacturing Companies in Nigeria. International Journal of Innovation and Economic Development, 3(3), 32-42. https://doi.org/10.18775/ijied.1849-7551-7020.2015.33.2003

Park, S. (1998). Industrial Development and Environmental Degradation. Edward Elgar Publishing, West Virginia.

Renwick, D.W., Redman, T., \& Maguire, S. (2012) Green Human Resource Management: A Review and Research Agenda, International Journal of Management Reviews, 15(1), 1-14. https://doi.org/10.1111/j.1468-2370.2011.00328.x

Saini, P., \& Shukla, K. K. (2016). Green Recruitment: A New Tool of Cost Cutting (Conceptual Study), International Journal of Scientific and Innovative Research, 4(1), 


\section{Macrothink \\ International Journal of Human Resource Studies \\ ISSN 2162-3058 2018, Vol. 8, No. 4}

195-198

Sanyal, L. (2017). Green Human Resource Management: Policies and Practices. African International Journal of Research in Management, 9(5), 43-55.

Sigh, P., Mathur, G., Jain, M., Sahayaraj, A. (2017). Recruitment \& Selection \& Its Impact on Organizational Productivity. International Journal Of Core Engineering \& Management, 4(2), 26-35.

Sriram, V. P., \& Sub, M. (2018).Impact of Green Human Resource Management (G-HRM)Practices over Organization Effectiveness. Journal of Advanced Research in Dynamical \& Control Systems. Special Issue, 386-394

Sudin, S. (2011). Strategic Green HRM: A proposed model that supports Corporate Environmental Citizenship. 2011 International Conference on Sociality and Economics Development IPEDR vol.10 (2011). IACSIT Press, Singapore.

Tang, G., Chen, Y., Jiang, Y., Paille, P., \& Jia, J. (2018). Green Human Resource Management Practices: Scale Development and Validity. Asia Pacific Journal of Human Resources, 56, 31-55. https://doi.org/10.1111/1744-7941.12147

Tomčíková, L. (2016). The effective recruitment and selection practices of organizations in the financial sector operating in the Slovak republic. Exclusive e-journal, Special issue, 1-7.

\section{Copyright Disclaimer}

Copyright for this article is retained by the author(s), with first publication rights granted to the journal.

This is an open-access article distributed under the terms and conditions of the Creative Commons Attribution license (http://creativecommons.org/licenses/by/4.0/). 